\title{
Trade Openness and Cocoa Output in Ondo State
}

\author{
Mrs. Mary Modupe Fasoranti (Ph. D) \\ Department of Economics, Adekunle Ajasin University \\ Akungba-Akoko, Ondo State, Nigeria PMB 001 \\ Tel: 80-3542-6122Ｅ-mail: olafasoranti@yahoo.com
}

Received: August 20, 2014 Accepted: September 9, 2014

doi:10.5296/ber.v4i2.6435 URL: http://dx.doi.org/10.5296/ber.v4i2.6435

\begin{abstract}
The study was carried out to provide further evidence on the concept of openness by examining its effect on cocoa output and the direction of causality between cocoa output and identified variables of interest in Ondo state. Data collected for the period 1980 - 2012 was analyzed using the dynamic ordinary least square (DOLS) method. The study also applied the error correction method and conducted both stationarity and co-integration tests. Results showed that all the variables were non-stationary at level but stationary at first difference i.e 1(1). The co-integration test showed the existence of co-integration among the variables implying the existence of sustainable long run relationship among the variables of interest. The ECM also showed that $57 \%$ of changes in the short run toward long run will be corrected per year. The result of granger causality test showed the evidence of unidirectional causality between cocoa output in Ondo State and ratio of credit to private sector, which run strictly from cocoa output in Ondo State to the ratio of credit to private sector. It follows from the result that increase in cocoa output will serve as a positive indicator that will encourage lending to cocoa farmer and subsequently boost productivity. The study concluded that trade openness did not significantly influence cocoa output in the study area while domestic price was significant, though negative. The study therefore recommends that the government should ensure that cocoa farmers are adequately motivated by getting appropriate value for their cocoa output.
\end{abstract}

Keywords: Trade openness, Causality, Gross domestic product.

\section{Introduction}

The classical and neoclassical economists attached so much importance to international trade. They regarded it as the engine of growth. The Mercantilist school of thought stressed the importance of trade as an important vehicle for promoting economic growth in less developed countries. They advocated that countries can acquire precious metals through trade, most 
importantly, the school emphasized surplus trade. They supported the exportation of goods with high quality. The school specifically stressed the need for the promotion of exports commodities. This is quite relevant for modern day government in that exports are necessary to finance the needed imports of machines, raw materials and the servicing of external debts. The current trend in the quest for rapid growth and development has led credence to the need for nation to engage in international trade.

The above scenario in addition to the adoption of the structural adjustment programme, led to the concept of trade openness. Trade openness is simply trade liberalization. It involves the removal or at worse the reduction of all barriers to the free flow of goods and service across national boundaries. Trade openness is expected to lower consumer costs, increase technical and allocative efficiency and increase growth. The idea of trade openness became an issue in Nigeria since the mid-eighties specifically 1986 when the Federal Government opted for the IMF loan and consequently adopted the structural adjustment programme. This led to trade policy reforms such as elimination of non-tariff barriers to imports, rationalization and reduction of tariffs, removal of fiscal disincentives and regulatory barriers to exports and the establishment of market determined exchange rates. In addition, regulation and restrictions hindering private participation in export trade were abolished.

However, the relationship between trade openness and economic performance indexed by GDP has been widely debated among economist over the years within and without the Nigerian economy. There is the constant fact that trade openness affects the growth of output but the debate has been on the direction of causality between trade openness and growth. Several studies provided evidence that trade openness is positively related with the growth of Gross Domestic Product (Ahmed and Anoruo, 2001; Yanikkaya, 2003; Edwards, 1998; Iscan, 1998 and Wacziarg, 2001), on the other hand, some other studies have shown that the growth of GDP stimulates the expansion of trade (Vernon, 1996 and Findlay, 1984). Moreover studies such as Rodrik and Rodriquez (2000) and Harrison and Hanson (1999) showed that trade openness has impacted negatively on the growth of the economy. This lack of consensus regarding the relationship between trade openness and economic growth forms the motivation for this study. Apart from this, most studies have been on the relationship between openness and growth with little attention on the effects of trade openness on specific crops that make up the Gross Domestic product. Hence this study has been designed to provide further evidence on the concept of openness by examining the effects of trade openness on cocoa production in Ondo State between 1976 and 2012. Also the study examined the direction of causality between cocoa output and the variables of interest employed in the study.

\section{Literature Review}

The clamor for trade openness is premised on the classical and neo-classical theories of free trade. Such theories include the absolute advantage theory, comparative advantage theory and the Heckscher-Ohlin theory of trade. These theories argued that trade among countries have the capacity of bringing numerous benefits to all participating countries. These theories postulated that greater openness will positively impact on the growth of the Gross Domestic products. Nevertheless, whether an economy will experience benefits or disbenefits depends on a 
number of factors. Oaikhean and Udegbunam (2008) identified factors such as the level of government subsidy on productive activities of the trading partner, size of the tariff imposed on imports entering into the country, availability of resources, capacity utilization of industries, exchange rate of domestic currency and skills technology.

The experience of the countries of the world have either supported or negated the theories of trade. Most especially, the economic performance of the less developed countries since their adoption of trade openness have been unimpressive over the years. Rieffe, (2005) identified the causes of such development as persistent depreciation of domestic currencies, persistent balance of payment disequilibrum and huge external indebtedness from trade credits.

Recent studies on the relationship between trade openness and growth include Asma and Hasnat (2012); Liargovas and Konstatinos (2012); Hur and Cheolbeom (2012); Elenya (2013); Anowor et al (2013); Muse (2014) and Ehinomen and Da'Sliva (2014). Asma and Hasnat (2012) examined the relationship between trade openness and output growth for Pakistan. Analyzing annual time series data between 1972-2010 with the aid of causality test and error correction modeling, the study showed a positive long run relationship between trade openness and output growth. Also the causality test showed a significant bidirectional relationship between trade openness and economic growth.

In a study on the relationship between trade openness and Foreign Direct Investment for thirty-six developing countries between 1990 and 2008. Liargovas and Konstatinos (2012) showed that trade openness contributed positively to the inflow of foreign direct investment in the long run. Sampling ninety developed and developing countries (1958-2003), Hur and Chealbeom (2012) showed that trade openness has statistically insignificant relationship with the growth of output during the first ten years but has significant relationship in later years. Applying the ordinary least square technique on data from Nigeria (1970-2008), Elenya (2013) showed that trade openness impacted significantly on the economic growth within the study period.

Anovor et al (2013) considered the impact of trade openness on Nigerian Agricultural sector with special bias toward the export sub sector. Two models were specified for the study to test the influence of the variables of interest on the performance of the Agricultural sector and the export -sub sector respectively. Their results revealed agricultural exports and imports price ratio and foreign investment on agriculture as significant variable affecting agricultural performance while agricultural degree of openness, agricultural capital formation and real exchange rate were statistically insignificant. On the other hand, agricultural degree of openness and foreign investment on agriculture significantly affected the agricultural export sub sector during the study period.

Ehinomen and Da'Silva(2014), using data between 1970 and 2010, showed a positive relationship between trade openness and output growth in Nigeria. The implication was that the economy will grow rapidly the more opened it is to the outside world.

Bernard (2014) examined the impact of trade openness on output between 1970 and 2012 in Nigeria. The study employed auto regressive distributive lag (ARDL), error correction 
modeling (ECM) and CUSUM and CUSUMSQ \& stability tests. The APDL bounds test showed no evidence of long run relationship between trade openness and economic growth. However, the study established an inverse relationship between trade openness and growth in the short run. This finding implied that economic growth has deleterious effect on trade in the short run.

Yanikkaya (2003) examined the impact of trade openness on per capital income growth for 120 countries between 1970 and1997. He identified and used two types of trade openness: openness based volume of trade i.e ratio of export and imports to GDP and openness based on trade restrictiveness (calculating restrictions on foreign exchange on bilateral payments and currency transactions). The study showed that trade openness based on trade volumes has significant and positive relationship with per capital income growth while trade openness based on trade restrictions has significant positive relationship with per capita output growth for developing countries.

Many other empirical studies in Nigeria have shown mixed findings for different time periods. Some of such studies include Olaifa et al (2013), Alimi and Atanda (2011), Obadan (2008), Nabine (2009), Fosu and Magnus (2006),Ndiyo and Ebong (2003) and Oaikhenam and Udegbunam (2008). Some of these studies suggested that trade openness has significant relationship with output growth while other declined.

Few literatures exist on the influence of trade openness on cocoa output in Nigeria. Idowu et al (2007) evaluated the effects of trade openness on cocoa output in six cocoa producing local government areas of South Western geopolitical zone in Nigeria. Using descriptive statistics and regression techniques, the study concluded that cocoa output has not increased but rather it had remained in the hands of small holder farmer with little application of chemical inputs.

There have been some earlier studies on the effects trade liberalization on cocoa output. Such studies include Adegeye and Dittoh (1988), and Idowu (1988); Adegeye (1991); CBN/NISER (1992);Alimi and Awoyomi (1995) and Akanji and Ukeje (1995). For these studies, the methods of analysis were descriptive statistics, budgetary analysis and production response functions analysis. The findings were majorly that trade liberalization has led to a tremendous increase in the cost of maintaining cocoa farms, producer prices and improvement in the gross margin per hectare.

This study differs from earlier studies on the effect of trade openness on output growth in that it is focused on the effect of trade openness on a specific crop i.e cocoa.

\section{Methodology}

\subsection{Sources of Data}

The study employed secondary data for the analysis. Data was collected from relevant issues of the Statistical Bulletin of the Central Bank of Nigeria, National Bureau of statistics and Ondo State Agricultural Development Project. Data was collected on cocoa output in Ondo State, World price of cocoa, Domestic price of cocoa, real exchange rate, and Trade Openness. 


\subsection{Method of Analysis}

The study used the Augmented Dickey Fuller (ADF) unit root to test the stationarity of the variables in this study. Thereafter, it employed Johasen's co-integration techniques to test the existence of long run relationship among the variables of interest. With regards to the estimation of co integration regression models, it is well known that the Ordinary Least Squares (OI.S) estimator contains the second order bias, comprising the endogeneity bias and the non-centrality bias, when the I(I) regressors are endogenous and/or the regression errors are serially correlated. Thus, several efficient methods for the estimation of the co integrating regressions have been proposed in the literatures. Thus, the study applied dynamic ordinary least squares (DOLS) method developed by Phillips and Loretan (1991), Saikkonen (1991) and Stock and Watson (1993). This is a parametric correction of OLS by adding leads lags of the first difference of the $\mathrm{I}(1)$ variables as regressors.

The most common way to test the causal relationship between two variables is the Granger-Causality proposed by Granger (1969). The test involves estimating the following simple vector autoregressions (VAR):

$$
\begin{aligned}
& X t=i Y t-i+j X t-j+\mu 1 t \\
& Y t=i X t-i+j Y t-j+\mu 2 t
\end{aligned}
$$

Where it is assumed that the disturbances $\mu 1 \mathrm{t}$ and $\mu 2 \mathrm{t}$ are uncorrelated. Equation (16) represents that variable $\mathrm{X}$ is decided by lagged variable $\mathrm{Y}$ and $\mathrm{X}$, so does equation (17) except that its dependent variable is $\mathrm{Y}$ instead of $\mathrm{X}$.

Granger-Causality means the lagged $\mathrm{Y}$ influence $\mathrm{X}$ significantly in equation (16) and the lagged $X$ influence $Y$ significantly in equation (17). In other words, researchers can jointly test if the estimated lagged coefficient $\Sigma \alpha i$ and $\Sigma \lambda j$ are different from zero with F-statistics. When the jointly test reject the two null hypotheses that $\Sigma \alpha i$ and $\Sigma \lambda j$ both are not different from zero, causal relationships between $\mathrm{X}$ and $\mathrm{Y}$ are confirmed. Thus, we applied the traditional Granger-Causality in this study.

Finally, the study examined the causal relations among variables within the framework of ECM, with co-integrated variables as demonstrated by Granger (19988). While the short run dynamics are captured by the individual coefficients of the lagged terms, the error correction term (ECT) contains the information of longrun causality. Significance of lagged explanatory variable depicts short run causality. Significance of lagged explanatory variables depicts short run causality while a negative and statistical significant ECT is assumed to signify long run causality (Bannerjee and Newman, 1998).

\subsection{Model Specification}

The following model was specified for the study

$\mathrm{CQ}=\mathrm{f}(\mathrm{WPc}, \mathrm{DPc}, \mathrm{RER}, \mathrm{TOP}, \mathrm{CPS})$

In a multiple linear regression form, model (i) becomes: 
$\mathrm{CQ}=\alpha 0+\alpha 1 \mathrm{Wpc}+\alpha 2 \mathrm{DPc}+\alpha 3 \mathrm{RER}+\alpha 4 \mathrm{TOP}+\alpha 5 \mathrm{CPS}+\mathrm{Ui}$

When transformed into a log-linear form, model (2) becomes

$\log \mathrm{CQ}=+\alpha 1 \log \mathrm{Wpc}+\alpha 2 \operatorname{LogDPc}+\alpha 3 \operatorname{LogRER}+\alpha 4 \log \mathrm{TOP}+\alpha 5 \mathrm{CPS}+\mathrm{Ui} \ldots$ (3)

Where:

Log CQ = logged value of cocoa output

Log WP = logged value of World prince of cocoa

Log DP $=$ logged value of domestic price of cocoa

Log RER = logged value of real exchange rate

Log TOP = logged value of trade openness index

Log CPS = logged value of credit to private sector as a percentage of gross domestic product.

Ui $=$ error term.

$\alpha 0 \alpha 6=$ Parameters to be estimated.

A prior expectations: $\quad \alpha 0>0 ; \alpha 1>0 ; \alpha 2>0 ; \quad \alpha 3>0 ; \quad \alpha 4>0 ; \quad \alpha 5>0$;

\section{Empirical Results on Discussion}

\subsection{Unit Root Test Result}

Table 1. ADF Unit Root Test

\begin{tabular}{|l|l|l|}
\hline Variables & At level & At first difference \\
\hline LogCq & -2.4845 & $-7.6119^{* * *}$ \\
\hline LogWp & -1.7362 & $-4.1235^{* * *}$ \\
\hline LogDp & -1.0580 & $-4.9072 * * *$ \\
\hline LogRER & -1.6811 & $-4.8316^{* * *}$ \\
\hline LogTOP & -2.5166 & $-6.0595 * * *$ \\
\hline LogCPS & -1.3400 & 0.0002 \\
\hline Critical values & $* * * 1 \%(-3.6537) ; * * 5 \%(-2.9571) ; * 10 \%(-2.6174)$ & \multicolumn{1}{|l}{} \\
\cline { 1 - 2 } &
\end{tabular}

The unit root results reported in Tables 1 show that all the series are non- stationary at level but become stationary after taking their first difference i.e I(1). Thus we apply the Johansen co-integration test to test long run relationship between the variables.

Table 2 provides the results from the application of Johansen co-integration test among the data set. Empirical findings show that both the maximum eigenvalue and the trace tests reject the null hypothesis of no co-integration of one while Max eigen show two co-integration rank. The results in Table 2 are based on the assumptions of linear deterministic trend and lag interval in first difference of 1 to 1 . We therefore conclude that there is existence of a sustainable long- run relationship among our variables of interest. 
Table 2. Result of Co-integration Test

\begin{tabular}{|l|l|l|l|l|}
\hline & Null Hypothesis & 0.05 Critical Values & Test Statistics & Prob. Value \\
\hline Trace Statistics & $\mathrm{r}=0$ & 95.75 & 118.56 & 0.0006 \\
\hline & $\mathrm{r}=1$ & 69.81 & 68.38 & 0.0648 \\
\hline Max-Eigen Statistics & $\mathrm{r}=0$ & 40.07 & 50.18 & 0.0027 \\
\hline & $\mathrm{r} \leq 1$ & 33.87 & 34.49 & 0.0422 \\
\hline Trace & No of vectors & & 1 & \\
\hline Max-Eigen & No of vectors & 2 & \\
\hline
\end{tabular}

As a result of the existence of co-integration relationship among the variable in the model, the study estimated the long- run relationships.

Dependent variable $=$ cocoa output $(\log \mathrm{Cq})$

Table 3. DOLS Long Run Coefficient Estimates

\begin{tabular}{|l|l|l|}
\hline Regressors & Coefficients & P-Value \\
\hline Constant & 8.6471 & 0.0823 \\
\hline LogDp & -0.9297 & 0.1105 \\
\hline LogWp & 0.8123 & 0.3182 \\
\hline LogCPS & 1.1293 & 0.1367 \\
\hline LogRER & 0.0890 & 0.6407 \\
\hline LogTOP & 0.0854 & 0.5690 \\
\hline $\begin{array}{l}\text { R-squared - 0.8748 } \\
\text { AdjustedR-squared- } 0.5965 \\
\text { Durbin- Watson stat - 2.3359 }\end{array}$ & & \\
\hline
\end{tabular}

$* * *, * *$ and $*$ shows statistical significance at $1 \%, 5 \%$, and $10 \%$ level.

Using dynamics ordinary least squares (DOLS), Tables 3 showed the coefficient estimate of the variables, their signs and probability values. The coefficients of all the variables were not statistically significant at five percent level. However, all variables except domestic price showed a positive relationship with the cocoa output in Ondo State. For example 1 percent rise in world price of cocoa suggest that cocoa output will grow by about 81 percent. Also, adjusted $\mathrm{R}$-squared suggested that the independent variables in the model provided about 60 percent information on the cocoa output (dependent variables).

The results of the dynamic of short run causality within the framework of ECM are as presented in table 4 ..

Table 4. ECM Short Run Coefficient Estimates

\begin{tabular}{|l|l|l|}
\hline Regressors & Coefficients & P-Value \\
\hline Constant & 0.0002 & 0.9968 \\
\hline$d(\log \mathrm{Cq}(-1))$ & 0.0057 & 0.9803 \\
\hline$d(\log \mathrm{Dp}(-1))$ & 0.1925 & $0.0466^{* * *}$ \\
\hline $\mathrm{d}(\log \mathrm{Wp}(-1))$ & -0.0766 & 0.6467 \\
\hline$d(\log \mathrm{CPS}(-1))$ & -.0 .0663 & 0.7939 \\
\hline$d(\operatorname{logRER}(-1))$ & -0.1580 & 0.3659 \\
\hline$d(\log \mathrm{TOP}(-1))$ & 0.0270 & 0.5309 \\
\hline Ecm(-1) & -0.5725 & 0.0221 \\
\hline
\end{tabular}

$* * * * *$ and $*$ shows statistical significance at $1 \%, 5 \%$, and $10 \%$ level. 
The results presented in Table 4 shows that only domestic price of cocoa significantly affected cocoa production in Ondo State. More so, the coefficients of ECM term in Table 4 was negatively and statistically significant, thus confirming the finding under Johansen-Juselius co-integration tests that there is evidence of long run causality between respective explanatory variable and its regressors. The estimate of lagged EC term also identified the speed of adjustment from short run towards long run equilibrium path. This showed that changes in short run towards long run is corrected by about 57 percent per year.

\subsection{Granger Causality Test}

Having established that a co-integrating relationship exist between among our variables of interest, the final step in this study is to verify if cocoa output Granger Cause the identified variable of interest using the pairwise granger causality test. The result of granger causality test is reported in Table 5.

Table 5. Result of Granger Causality Test

\begin{tabular}{|c|c|c|c|}
\hline Null Hypothesis & F-Statistic & Prob. & Conclusion \\
\hline LogCq does not Granger Cause LogCPS & 2.74965 & 0.0826 & \multirow{2}{*}{$\begin{array}{l}\text { Unidirectional Causality } \\
\log C q \rightarrow \log C P S\end{array}$} \\
\hline LogCPS does not Granger Cause LogCq & 1.49292 & 0.2434 & \\
\hline LogDP does not Granger Cause LogCq & 1.40379 & 0.2637 & \multirow[t]{2}{*}{ No Causality } \\
\hline LogCq does not Granger Cause LogDP & 0.53015 & 0.5947 & \\
\hline LogRER does not Granger Cause $\log C q$ & 0.00670 & 0.9933 & \multirow[t]{2}{*}{ No Causality } \\
\hline LogCq does not Granger Cause LogRER & 1.98310 & 0.1579 & \\
\hline LogTop does not Granger Cause $\log C q$ & 0.58327 & 0.5652 & \multirow[t]{2}{*}{ No Causality } \\
\hline LogCq does not Granger Cause LogTop & 1.01192 & 0.3774 & \\
\hline LogWp does not Granger Cause $\log C q$ & 0.29749 & 0.7452 & \multirow[t]{2}{*}{ No Causality } \\
\hline LogCq does not Granger Cause LogWp & 1.18575 & 0.3215 & \\
\hline
\end{tabular}

It is clear from Table 5 that there is a unidirectional causality between cocoa output in Ondo State and ratio of credit to private sector, a measure of financial development in Nigeria. The causality run strictly from cocoa output in Ondo State to the ratio of credit to private sector. It follows from the result that increase in cocoa output will serve as a positive indicator that will encourage lending to cocoa farmer and subsequently boost productivity. However, the rests show no causality results between cocoa output in Ondo State and identified variables in this study.

\section{Summary, Conclusion and Recommendation}

The study considered the effects of trade openness on cocoa output in Ondo State. Data sourced from secondary sources were analysed with the aid of Dynamic Ordinary Least Square (DOLS) method, Johansen's co-integration test, ADF Unit Root test and Error Correction Modeling. Results showed that all variables were stationary at first difference. All independent variables were positively related to cocoa output except domestic price which contradicted a priori expectation. Only domestic price of cocoa was statistically significant while others were not though positive. The study concluded that trade openness have positive influence on cocoa output in Ondo State but it was not a significant factor in cocoa output during the period of study. Also credit to private sector as a percentage of gross domestic product, though positive has no significant influence on cocoa ouput. The granger causality test showed the evidence of 
unidirectional causality between cocoa output in Ondo State and ratio of credit to private sector, which run strictly from cocoa output in Ondo State to the ratio of credit to private sector. It follows from the result that increase in cocoa output will serve as a positive indicator that will encourage lending to cocoa farmer and subsequently boost productivity. The study hereby recommends more credit accessibility for farmers and that the government should enhance the domestic price of cocoa.

\section{References}

Adegeye, A. J., \& Dittoh, J. S. (1988). Is there a Structurally Adjusted Induced Boom in the Nigerian Cocoa Industry? Paper presented at the 1988 Annual Conference of the Nigerian Association of Agricultural Economists, OAU, Ile-Ife, 3rd-7th, May.

Adegeye, A. J. (1991). A Comparative Analysis of the Cost of Production and Producer Prices of a Tonne of Cocoa from matured trees in Nigeria before and during the Structural Adjustment Programme. Ife Journal of Agriculture, 2, 14-18

Ahmed, Y., \& Anoruo, E. (2000). Openness and Economic Growth: Evidence from selected ASEAN countries. The Indian Economic Journal, 47(3), 110-117

Alimi, A. Y., \& A. A. Atanda (2011). Globalization, Business Cycle and Economic Growth. African Journal of Scientific Research. 7(1).

Anowor, O. F., Ukweni, N. O., \& Martins, I. (2013). The Impact of Trade Liberalization on Nigeria Agricultural Sector, Journal of Economics and Sustainable Development. 4(8), 14-24.

Asma Arif \& Hasnet Ahmed (2012). Impact of Trade Openness on Output Growth: Co integration and Error Correction Model Approach. International Journal of Economics and Financial Issues, 2(4), 379-385.

Bannerjee, A. V., \& Newman, A. F. (1998). Occupational Chioce and the Process of Development. Journal of Political Economy. 101, 274-298. http://dx.doi.org/10.1086/261876

Bernard O. Muse (2014). An Auto regressive Distributive Lag approach to Co integration: An examination of Trade Openness and Economic Growth Relationship in Nigeria. Research Journal of Economics and Business Studies. 3(3), 85-91

CBN/NISER (1992). The Impact of SAP on Nigerian Agriculture and Rural Life.

Edwards, S. (1998). Openness, Productivity and Growth: What do we really know? Economic Journal, 108, 383-398 http://dx.doi.org/10.1111/1468-0297.00293

Ehinowen, Christopher \& Da'Silva Damilola (2014). Impact of Trade Openness on the Output Growth in the Nigerian Economy. British Journal of Economics, Management and Trade, 4(5). 755-768.

Eleanya Kalu Nduka (2013). Openness and Economic Growth in Nigeria. Journal of Education and Practice, 4(1), 68-73.

Evans S. C. Osabuohien (2007). Trade Openness and Economic Performance of ECOWAS 


\section{Macrothink}

Business and Economic Research ISSN 2162-4860 2014, Vol. 4, No. 2

Members Reflections from Ghana and Nigeria. African Journal of Business and Economic Research. 2(2\&3), 57-73.

Fosu, O. A. E., \& Magnus, J. F. (2006). Bound Testing Approach to co-integration: An examination of foreign direct investment, trade and growth relationships. American Journal of Applied Sciences, 3(11), 2079-2085. http://dx.doi.org/10.3844/ajassp.2006.2079.2085

Granger, C. W. J., (1988). Causality, Co integration and Control. Journal of Economic Dynamics and Control, 12, 551-559. http://dx.doi.org/10.1016/0165-1889(88)90055-3

Harrison, Ann \& Gordon Hanson (1990). Who Gains From Trade Reform? Some Remaining Puzzles. Journal of Development Economics, 59(1), 125-54. http://dx.doi.org/10.1016/S0304-3878(99)00008-5

Hur, J., Cheolbeom, P (2012). Do free Trade Agreements Increase Economic Growth of the Member Countries? World Development, 40(7), 1283-1294. http://dx.doi.org/10.1016/j.worlddev.2011.12.006

Idowu, E. O. (1988). The cocoa Industry and Employment Generation in Nigeria: A Case Study of Ondo State. In Idoani et al (2007) Effects of Market Deregulation on Cocoa (Theobroma Cacao) Production in South West Nigeria, Africa. Journal of Agricultural Research, 2(9), 429-434.

Iscan, T. (1998). Growth and Development in Trade Models in International Journal of Economics and Financial Issues, 2(4), 2012.

Lairgovas, P. G., \& Konstantions, S. S. (2012). Foreign Direct Investment and Trade Openness: The Case of Developing Countries. Social Indicator Research, 106, 323-331. http://dx.doi.org/10.1007/s11205-011-9806-9

Nabine, D. (2009). The Impact of Chinese Investment and Trade on Nigeria Economic Growth. Africa Trade Policy Center Work in Progress No. 77, Economic Commssion of Africa, Addis Ababa.

Nigido, N. A., \& F. S. Ebong (2003). The Challenge of Openness in Developing Economics: Some Empirical Lessons from Nigeria. Proceedings of the Nigerian Economic Society's Annual Conference.

Oaikhenam, H. E., \& Udegbunam, R. I. (2008). Openness, Capital flows and Economic Growth in Nigeria: Empirical Evidence. Nigeria Journal of Economic and Social Studies. 50(2), 257-280.

Obadan, M. I (2008). Economic Globalization, Markets and National Development: How Sensibly do the Poor Countries (Nigeria Included) Stand? Inaugural Lecture series 98, University of Benin, Benin City.

Olaifa, F. G., Subair, K., \& Biala, M. I. (2013). Trade liberalization and Economic Growth. African Journal of Scientific Research. 7(1).

Phillips, P. C. B., \& M. Loretan (1991). Estimating Long-Run Economic Equilibria. Review of 
Economic Studies. 58, 407-436. http://dx.doi.org/10.2307/2298004

Rodrik, D. F., \& Rodriquez (2000). Trade Policy and Economic Growth. A Sceptic guide to Cross- National Evidence In: H. E. Oaikhenan and R. I. Udegbanam (2008). Openness: Capital Flows and Economic Growth in Nigeria: Empirical evidence. Nigerian Journal of Economic and Social Studies.

Saikkonen, P. (1991). Asympototically Efficient Estimation of Co-integration Regressions. Econometric Theory. 7, 1-21. http://dx.doi.org/10.1017/S0266466600004217

Vernon, R. (1996). International Investment and International Trade in the Product Cycle. Quarterly Journal of Economics. 80, 190-207. http://dx.doi.org/10.2307/1880689

Yanikkaya, H. (2003). Trade Openness and Economic Growth: Evidence from selected ASEAN Countries. The Indian Economic Journal. 47(3), 110-117.

\section{Copyright Disclaimer}

Copyright for this article is retained by the author(s), with first publication rights granted to the journal.

This is an open-access article distributed under the terms and conditions of the Creative Commons Attribution license (http://creativecommons.org/licenses/by/3.0/). 